\title{
The Effect of Board Independence and Board Meeting on Firm Performance: Evidence from Jordan
}

\author{
Almontaser Abdallah Mohammad Qadorah, Faudziah Hanim Bt Fadzil \\ Othman Yeop Abdullah Graduate School of Business, Universiti Utara Malaysia, Sintok, Malaysia \\ Email address: \\ nasr.uum@gmail.com (A. A. M. Qadorah)

\section{To cite this article:} \\ Almontaser Abdallah Mohammad Qadorah, Faudziah Hanim Bt Fadzil. The Effect of Board Independence and Board Meeting on Firm \\ Performance: Evidence from Jordan. Journal of Finance and Accounting. Vol. 6, No. 5, 2018, pp. 105-109. doi: 10.11648/j.jfa.20180605.11
}

Received: September 19, 2018; Accepted: October 9, 2018; Published: October 29, 2018

\begin{abstract}
The purpose of this study to examine the relationship between the internal corporate governance mechanism related to the board of directors' characteristics namely (board independence and frequency of board meetings) and firm performance in Jordanian listed firms. The study used Cross-sectional data for the year 2013, with a sample of 64 industrial firms listed in the Amman Stock Exchange. Firm performance was measured by return on assets (ROA) as an accountingbased performance measure. The current study utilized multiple linear regression analysis to test the hypotheses and examine the relationship between the board of directors' characteristics namely (board independence and frequency of board meetings) and firm performance. The findings showed that board independence is significantly and positively related to ROA. The current study found an insignificant relationship between the frequency of board meetings and firm performance measured by ROA. These results indicate that the monitoring role of the more independent board could have a significant influence on firm performance. Contradictory to expectation, the result of this study reveals that the frequency of board meetings do not determine the performance of industrial Jordanian firms. Further, Current study findings provide the idea to future researchers for further empirically explore the importance of the board of director's characteristics in Jordan. This study provides several important implications for the theory, regulatory authorities and policy makers and academia and researchers.
\end{abstract}

Keywords: Corporate Governance, Board of Director's Independence, Board Meeting, Firm Performance

\section{Introduction}

In the current global business environment, business organizations increase their continued struggle to achieve a high record of growth to attract investors who will be willing to finance the future investment projects of their firms. In today's competitive business environment stability and profitability are key factors influencing the decision to invest in firms [1]. This justifies the inability of deteriorating businesses to raise funds for their investment projects. This situation can affect not only the specific business organisations but also the overall economic performance. To safeguard and protect the firm business environment, governments throughout the world have been enhancing effort for the implementation of corporate governance mechanisms. Moreover, "good corporate governance is essential for the economic growth led by the private sector and for the promotion of the social welfare" [2].

Similarly, Li, Bruton and Filatotchev reviewed the relevant literature in the field of corporate governance and identified two ways through which the corporate governance mechanisms can affect firm's financial performance [3]. First, it can broaden the access to financial resources that enhance company's profitability and growth through new project investments. Second, it can help the company to minimize the cost of capital and enhance the overall company value.

This study purposes to look at the effect of BOD independence and board meeting frequency on the performance of listed firms in Amman Stock Exchange. Prior empirical studies in developed and developing countries have been considered for the current study research framework. The prior literature also used to develop hypotheses for objective attainment. According to preceding studies, there are many ways to measure corporate governance, however, this study will consider only: (i) board of director's independence; and (ii) board meeting frequency. Similarly, 
prior studies also suggested return on asset (ROA) as a measurement of firm financial performance.

Further, the remaining part of this paper consists of literature review, research methodology, analysis, and discussion. Furthermore, this paper provides some recommendations for future studies.

\section{Literature Review and Hypotheses}

Evidence from previous empirical studies from academic literature has sought to confirm the effect of corporate governance on a firm's financial performance. A literature review from relevant academic studies have indicated the following characteristics applied to corporate governance such as: (i) board of director's independence; and (ii) board meetings frequency. Each of these characteristics are discussed in detail below.

There are many empirical prior studies regarding the relationship between corporate governance and firm financial performance. Previous studies indicated that there are some characteristics of corporate governance. Most of the studies empirically proved that the board of director independence and board meeting frequency are the significant characteristics of corporate governance. This section will briefly describe the literature on both of these characteristics in below.

\subsection{Board of Director's Independence}

Board independence relies on the firm which is considered as a primary incentive for board monitoring. Bosse and Phillips suggests that independent of the board of directors is an added value to a firm as it increase the responsibility, provide judgment of self-governance, increase business network connections between the board and executive, and moderating the power of the CEO and chairman of the board which in many companies is an adequately powerful [4]. Thus, when the non-executive or outside directors are independent from the management, there could be the possibility of providing superior benefits to the firm financial performance.

On the other side, a negative effect of high board of director's independence on firm financial performance was found by [5]. Primarily, their work were conducted on the influence of board composition of firm financial performance with the integration of significant ownership concentration among listed Canadian firms covering the period of 1993 to 1997. It was revealed by their study that firms that increase the proportion of outside in the following year's director performed poorly compared to others. Thus, the suggestion has been made that inclusion of outside directors will boost the firms' financial performance.

Board of director's independence exhibits that board members do not depend on the CEO and management due to its composition issues. External board members are not involved in the daily firm operations, but they are more likely to cogitate more independent when it comes to the financial performance of the firm. Moreover, their experiences support in generating novel perspectives and ideas regarding earning performance [6]. Similarly, the main role of non-executive directors is to provide protection to shareholders' interests while making firms decisions [7].

The agency theory stated that an essential conflict among the interests of the owner and manager in firm [8, 9]. For corporate governance, the agency theory shows that inadequate monitoring approaches should be secured shareholders from mean attitude of management. Thus, the majority of external directors on the board are considered to have a positive effect on firm financial performance $[8,10]$.

Few researches do not show effect of non-executive directors on the board and firm financial performance [1114]. However, there are also number of researches that do not show any improvement in the firm financial performance due to outside directors of the board; for instance, Armstrong, Core and Guay described that there is a significant relationship between the board composition and firm financial performance, also stated that firms with less-profit must have to face business issue through great wisdom and high rate of independent board directors [15]. Hence, the first hypothesis is as follows:

$\mathrm{H}_{1}$ : There is a positive relationship between independence board of director's and firm financial performance.

\subsection{Frequency of Board Meetings}

Owing to the board effectiveness importance on firm financial performance, numerous studies were conducted in various developed and developing countries. Finding from developed countries assured the positive relationship between BOD meetings and firm financial performance [16-20]. Likewise, in the developing countries studies confirmed such positive relationship such as [21-26]. Contrarily, some studies revealed the negative influence of the board meeting on firm financial performance in developed countries such as [27-29]. Such negative influence was also discovered in developing countries [26, 30-32]. Nevertheless, some studies document the insignificant relationship between board meetings and performance of firms [16, 32, 33]. Hence, the second hypothesis is as follows:

$\mathrm{H} 2$ : There is a positive relationship between board meetings frequency and firm financial performance.

\section{Measurement of Variables}

This study used variables for empirical test which are: (1) firm financial performance as dependent variable; (2) Board independence and board meeting frequency as independent variables. The table below exhibits the variables measurement with prior employed studies references. 
Table 1. Measurements of Variables in the Study.

\begin{tabular}{lll}
\hline Variables & Definition & Measurement \\
\hline Dependent variable ROA & Return on asset & Earnings (before tax) divided by total assets of the firm \\
Independent variables IND & Board of director's independence & the percentage of independent directors on the board (\% indep) \\
FBMET & Board meetings frequency & number of meetings held by BOD's during a year \\
\hline
\end{tabular}

\section{Sample of Data}

The population for this study is the industrial firms listed at Amman Stock Exchange (ASE) Jordan, which are divided into 10 sub-sectors and comprised of 64 firms. Secondary data using annual report was utilized for the purpose of the study for the industrial firms listed on ASE for the year 2013.

The selection of 64 firms as a sample in this study is expected to give the clear and comprehensive result. Furthermore, these listed companies would provide information about compliance with the code of corporate governance (CCG). It is anticipated those companies have good practices of corporate governance as they are required to disclose compliance with CCG in their financial reporting.

Table 2. Descriptive Statistics of Variables.

\begin{tabular}{llllll}
\hline Variables & N & Minimum & Maximum & Mean & Std. Dev. \\
\hline IND & 64 & 0.40 & 1.00 & 0.92 & 0.19 \\
FBMET & 64 & 6.00 & 12.00 & 7.33 & 1.46 \\
ROA & 64 & -0.29 & 0.29 & 0.02 & 0.09 \\
\hline
\end{tabular}

\section{Results and Discussions}

Table 3 shows the correlations between the independent variables and dependent variable. From the output, it is clear that independent variables including independence of the BOD's (IND) and Frequency of Board Meeting (BMEET) are positively correlated with (ROA).
The value for correlation between independence of the BOD's (IND) and ROA is a positive 0.38 . The positive sign means that ROA increases as the number of independent directors' increases, and vice versa. To see the strength of the relationship between ROA and independence of the BOD's (IND), the value of correlation is assessed using the 2-tailed test. Based on the value of 0.38 , it can be determined that there is a weak effect of independence of the BOD's (IND) on ROA at 0.05 by using the 2-tailed test. Other studies also showed positive effects of the number of independent BOD's on ROA such as [34, 35].

Furthermore, frequency of board meeting (FBMET) shows an insignificant positive 0.04 correlations with ROA at 0.05 using the 2-tailed test. Thus, this implies due to non-existence of significant correlation between the board meeting frequency and financial performance of firm as measured by ROA. Past studies also revealed board meeting and the firm financial performance positive relationship $[28,30]$.

Table 3. Correlation Matrix among Variables.

\begin{tabular}{llll}
\hline Variables & ROA & IND & FBMET \\
\hline ROA & 1 & & \\
IND & 0.38 & 1 & \\
FBMET & 0.04 & -0.09 & 1 \\
\hline
\end{tabular}

Table 4 demonstrated the result for the multiple regression models with firm financial performance. This table showed the value of $\mathrm{R}$ Square and adjusted $\mathrm{R}$ Square for the regression model.

$$
\mathrm{ROA}=\alpha 0+\beta 1 \mathrm{IND}+\beta 2 \mathrm{FBMET}+\varepsilon
$$

Table 4. Multiple Regressions.

\begin{tabular}{lllll}
\hline Model & R & R Square & Adjusted R Square & Std. Error of Estimates \\
\hline & 384 & 148 & 120 & 086 \\
\hline
\end{tabular}

Table 4 displays multiple regression model results for the dependent variable; ROA. From the table, it showed the value for adjusted R Square is 0.12 indicating $12 \%$ strength of the independence of the BOD's and Frequency of Board Meeting with firm financial performance. $\mathrm{R}$ square statistically measure coefficient of multiple determination for multiple regression.

Table 5. Anova.

\begin{tabular}{llllll}
\hline Model & Sum of quares & df. & Mean Square & F & Sig. \\
\hline Regression & 077 & 2 & 039 & 5.278 & .008 \\
Residual & 447 & 61 & 007 & & \\
Total & 524 & 63 & & & \\
\hline
\end{tabular}

Another measure to see if the model is good in predicting firm financial performance is the significance of the value of F. Based on Table 5, the value is 0.008 . Since the value is less than 0.05 , the whole regression is said to have a good fit.
Table 6. Coefficients.

\begin{tabular}{|c|c|c|c|c|}
\hline \multirow{2}{*}{ Model } & \multicolumn{2}{|c|}{ Unstandardized Coefficients } & \multirow{2}{*}{$\mathbf{T}$} & \multirow{2}{*}{ Sig. } \\
\hline & B & Std. Error & & \\
\hline Constant & -284 & 105 & -2.713 & 009 \\
\hline IND & 296 & 092 & 3.230 & 002 \\
\hline FBMET & 005 & 007 & 630 & 531 \\
\hline
\end{tabular}

Regarding the independence of the BOD's, the result shows that it is significantly related to ROA. This study provides the support to prior studies argued that in developing nations, some directors may not prospective for the reduction in agency conflicts which related to possible excess resources mismanagement, because of the fact that they were not elected based on their skills and experience, rather it is mostly due to political causes, for legitimating business operations, for associations and agreements [36, 37]. Also, few studies do not represent that there is no 
relationship between independence of the BOD's and ROA such as [11-13].

Furthermore, Table 6 also illustrates that frequency of board meeting have no effect on ROA this is in agreement with past studies findings $[16,32]$.

Table 7. Summary of the Hypothesis Testing.

\begin{tabular}{lll}
\hline Number & Hypothesis & Result \\
\hline H1 & There is a positive relationship between independence board of director's and firm financial performance. & Supported \\
H2 & There is a positive relationship between board meetings frequency and firm financial performance. & Not Supported \\
\hline
\end{tabular}

\section{Conclusions}

The first objective was to determine the influence of independence of the BOD's on firm financial performance. In order to accomplish this objective, hypothesis was affirmed as "there is a positive relationship between independence of the BOD's and firm financial performance". Accordingly, the regression analysis result showed that independence of the BOD's had a positive effect on firm financial performance (ROA). Consequently, this finding supported the hypothesis. This study is aligned with [38-40] findings. The findings of current study followed the agency theory which discuss the independent director's effect on the firm board that minimize agency difficulties. Therefore, it can be concluded that a high level of BOD independence enhances firms' financial performance.

The second objective was to determine the influence of board meeting frequency on firm financial performance. In order to accomplish this objective, hypothesis was affirmed as "there is a positive relationship between frequency of board meetings and firm financial performance". Accordingly, the regression analysis result showed that frequency of board meeting had no significant effect on firm financial performance (ROA). Consequently, this finding does not support the hypothesis. This result followed the findings of $[16,32]$. Therefore, it can be concluded that a lower number of board meeting will enhance firms' financial performance.

This finding can be justified based on many reasons such as differences in corporate law, capital markets, internal capital structure of the firm, and structure of company ownership. The aforementioned factors are different as applied in Amman Stock Exchange compared to developed countries, which may have had a hand in influencing the relationship. Moreover, the present study has been conducted in 2015 relying on 2013 data for industrial listed firms in Amman Stock Exchange. Owing to the early stage of implementation of corporate governance in Jordan, the rules for governance and control mechanisms have still not been effectively enforced, which may affect the board meeting frequency and firm financial performance relationship.

Current study findings provide the idea to future researchers for further empirically explore the importance of board of director's characteristics in Jordan. As long as the implementation of the Corporate Governance Code is at its initial stage in Jordan, the gap leads to vague explanations and requires further studies. Therefore, this study can encourage and highlights some recommendations for future studies to be conducted in the area of interest, and to overcome the limitation encountered by this study. The recommendations are highlighted as follows:

Include other listed firms either the industrial firms by making use of a different method such as financial and services firms.

Consider other financial performance measurement such as EPS, ROE, Tobin's Q and ROI.

Extend the period of using data for more than one year, through time-series or panel data analyses.

Consider other aspects of BOD's characteristics variables that are not included in the current study to further examine firm financial performance. Such variables may include remuneration and nominating committees, the board of director's frequency and experience of the board of directors.

\section{References}

[1] Carroll, A., \& Buchholtz, A. (2014). Business and society: Ethics, sustainability, and stakeholder management. Nelson Education.

[2] Honoré, F., Munari, F. and de La Potterie, B. V. P., 2015. Corporate governance practices and companies' R\&D intensity: Evidence from European countries. Research policy, 44(2), pp. 533-543.

[3] Li, W., Bruton, G. D., \& Filatotchev, I. (2016). Mitigating the dual liability of newness and foreignness in capital markets: The role of returnee independent directors. Journal of World Business, 51(5), 787-799.

[4] Bosse, D. A., \& Phillips, R. A. (2016). Agency theory and bounded self-interest. Academy of Management Review, 41(2), 276-297.

[5] Ramachandran, J., Ngete, Z. A., Subramanian, R., \&Sambasivan, M. (2015). Does corporate governance influence earnings management? Evidence from Singapore. The Journal of Developing Areas, 49(3), 263-274.

[6] Swamy, V. (2011). Corporate Governance and Firm Performance in Unlisted Family Owned Firms. International Journal of Business Insights \& Transformation, 4(2).

[7] Bhaduri, S. N., \& Selarka, E. (2016). Corporate Governance: An Overview. In Corporate Governance and Corporate Social Responsibility of Indian Companies (pp. 61-72). Springer Singapore.

[8] Fama, E., \& Jensen, M. (1983). Agency problems and residual claims. The Journal of Law and Economics, 26(2), 327-349.

[9] Lin, Z. J., Liu, M., \& Zhang, X. (2016). The Development of Corporate Governance in China. Asia-Pacific Management Accounting Journal, 1(1). 
[10] Jensen, M., \& Meckling, W. (1976). Theory of the firm: managerial behavior, agency costs and ownership structure. Financial Economics, (3(4), 305-360.

[11] Chin, T., Vos, E., \& Case, Q. (2004). Levels of ownership structure, board composition and board size seem unimportant in New Zealand. Corporate Ownership and Control, 2, 119-128.

[12] Fosberg, R. H. (1989). Outside directors and managerial monitoring. Akron Business and Economic Review, 20(2), 24.

[13] Klein, P., Shapiro, D., \& Young, J. (2005). Corporate governance, family ownership and firm value: the Canadian evidence. Corporate Governance: An International Review, 13(6), 769-784.

[14] Azeez, A. A. (2015). Corporate governance and firm performance: evidence from Sri Lanka. Journal of Finance, $3(1), 180-189$.

[15] Armstrong, C. S., Core, J. E., \& Guay, W. R. (2014). Do independent directors cause improvements in firm transparency? Journal of financial economics, 113(3), 383403.

[16] Gavrea. C., \& Stegerean. R. (2012). Corporate governance and firm performance: The Romanian case. Managerial Challenges of the Contemporary Society, 3(1), 179-185.

[17] Khanchel, 1. (2007). corporate governance: measurement and determinant analysis. Managerial Auditing Journal, 22(8), 740-760.

[18] Liang. Q., Xu, P., \& Jiraporn, P. (2013). Board characteristics and Chinese bank performance. Journal of Banking \& Finance, 37(8), 2953-2968.

[19] Lin, S. \& Hu. S. (2002). A family member or professional management? The choice of a CEO and its impact on performance. Corporate Governance, 15(6), 1348-1363.

[20] Liao, L., Lin, T. P., \& Zhang, Y. (2016). Corporate Board and Corporate Social Responsibility Assurance: Evidence from China. Journal of Business Ethics, 1-15.

[21] Saeidi, S. P., Sofian, S., Saeidi, P., Saeidi, S. P., \& Saaeidi, S. A. (2015). How does corporate social responsibility contribute to firm financial performance? The mediating role of competitive advantage, reputation, and customer satisfaction. Journal of Business Research, 68(2), 341-350.

[22] Sahu, T. N., \& Manna, A. (2013). Impact of Board Composition and Board Meeting On Firms' Performance: A Study of Selected Indian Companies. Vilakshan: The XIMB Journal of Management, 10(2).

[23] Khan, M., \& Javid, A. (2011). Determinants of board effectiveness: Logit model ferheenkayani. Interdisciplinary Journal of Contemporary Research in Business, 3(2). 19701981.

[24] Kang, S. A., \& Kim, Y. S. (2011). Does earnings management amplify the association between corporate governance and firm performance? Evidence from Korea. International Business \& Economics Research Journal (IBER), 10 (2).

[25] Hsu, W., \&Petchsakulwong, P. (2010). The impact of corporate governance on the efficiency performance of the Thai non-life insurance industry. The Geneva Papers on Risk and Insurance Issues and Practice, 35(1), S28-S49.
[26] Kamardin, H. (2009). The impact of corporate governance and board performance on the performance of public listed companies in Malaysia. Ph. D. Dissertation, University Sains Malaysia.

[27] Zattoni, A., Gnan, L., \&Huse, M. (2015). Does family involvement influence firm performance? Exploring the mediating effects of board processes and tasks. Journal of Management, 41(4), 1214-1243.

[28] Garcia-Sanchez, I. M. (2010). The effectiveness of corporate governance: Board structure and business technical efficiency in Spain. CEJOR, 18, 311-339.

[29] Wu, Q., Wang, P., \& Yin, J. (2007). Audit committee, board characteristics and quality of financial reporting: An empirical research on Chinese securities market. Frontiers of Business Research in China, 1(3), 385-400.

[30] Danoshana, S., \& Ravivathani, T. (2014). Impact of corporate governance framework on the organizational performance. A study on financial institutions in Sri Lanka International Journal of Technological Exploration and Learning, 16(1), 73-78.

[31] Ahmed Sheikh, N., Wang, Z., \& Khan, S. (2013). The impact of internal attributes of corporate governance on firm performance: evidence from Pakistan. International Journal of Commerce and Management, 23(1), 38-55.

[32] Noor, M. A. M. (2011). The effect of implementation of Malaysia code of corporate governance (MCCG) 2007 on corporate governance attributes and financial performance. Ph. D. DPA Dissertation, University Utara Malaysia.

[33] Al-Najjar, B. (2014). Corporate governance, tourism growth and firm performance: Evidence from publicly listed tourism firms in five Middle Eastern countries. Tourism Management, 42, 342-351.

[34] Honeine, S., \& Swan, P. (2010). Is company performance dependent on outside director 'skin in the game?'. Available at SSRN 1746536.

[35] Masulis, R. W., Wang, C., \& Xie, F. (2012). Globalizing the boardroom - the effects of foreign directors on corporate governance and firm performance. Journal of Accounting and Economics, 53(3), 527-554.

[36] De Andres, P. Azofra, V. \& Lopez, F. (2005). Corporate boards in OECD countries: Size, composition, functioning and effectiveness. An International Review, 13(2), 197-210.

[37] Haniffa, R., \& Hudaib, M. (2006). Corporate governance structure and performance of Malaysian listed companies. Journal of Business Finance \& Accounting, 33(7), 1034-1062.

[38] Krivogorsky, V. (2006). Ownership, board structure, and performance in continental Europe. International Journal of Accounting, 41(2), 176-197.

[39] Lefort, F., \&Urzua, F. (2008). Board independence, firm performance and ownership concentration: Evidence from Chile. Journal of Business Research, 61(6), 615-622.

[40] Limpaphayom, J., Connelly, P. (2006). Board characteristics and firm performance: evidence from the life insurance industry in Thailand Chulalongkorn. Journal of Economics, 16(2), 101-124. 